\title{
Evaluasi Safety Attitude Culture pada Perawat di Ruang Operasi PKU Muhammadiyah Gamping
}

\author{
Irma Wulandari ${ }^{1 *}$, Titih Huriah ${ }^{2}$, Sri Sundari ${ }^{3}$ \\ ${ }^{1}$ Mahasiswa Magister Manajemen Rumah Sakit, Universitas Muhammdiyah Yogyakarta \\ ${ }^{2,3}$ Fakultas Kedokteran dan Ilmu Kesehatan, Universitas Muhammdiyah Yogyakarta \\ *Correspondence e-mail: wulannatalludin@ymail.com
}

\begin{abstract}
Abstrak. Di Indonesia, kejadian medical error tergolong cukup tinggi terbukti dengan adanya laporan insiden RS, dimana di tahun 2010 terdapat $75 \%$ kejadian yang tidak diharapkan dan pada tahun 2011 sebanyak $60 \%$ kejadian kasus bedah atau pasien dengan tindakan operasi. Medical error salah satunya kejadian yang tidak diinginkan (KTD), yang terjadi di berbagai Negara maka mulai dikembangkan sistem keselamatan pasien (patient safety). Agar dapat menjalankan fungsi tersebut, rumah sakit harus mampu menjalankan manajemen yang berprinsip pada customer oriented dan patient safety dengan menerapkan safety attitude culture. Tujuan penelitian ini adalah mengetahui evaluasi safety attitude culture pada perawat di ruang operasi PKU Muhammadiyah Gamping. Penelitian ini merupakan penelitian yang menggunakan pendekatan mixed methods research yaitu metode kuantitatif dengan pendekatan deskriptif dan metode kualitatif dengan pendekatan studi kasus (case study). Populasi dalam penelitian ini adalah perawat ruang operasi dengan teknik pengambilan sampel total sampling sampel 20 orang. Kuesioner dalam penelitian ini mengacu pada Operating Room Version of Safety Attitudes Questionnaire. Analisis data kuantitatif menggunakan analisis deskriptif sedangkan analisis kualitatif dilakukan dengan reduksi data, penyajian data, dan penarikan kesimpulan/verifikasi. Hasil penelitian menunjukkan bahwa secara keseluruhan evaluasi safety attitude culture pada perawat di ruang operasi disimpulkan dalam kategori tinggi (75,0\%). Sedagkan berdasarkan komonen safety attitude culture yaitu iklim keselamatan dalam kategori tinggi $(85,0 \%)$, iklim kerja tim dalam kategori tinggi $(90,0 \%)$, pengakuan stress dalam kategori tinggi $(65,0 \%)$, persepsi manajemen dalam kategori sedang $(75,0 \%)$, kondisi kerja dalam kategori tinggi $(60,0 \%)$, kepuasan kerja dalam kategori tinggi $(90,0 \%)$.
\end{abstract}

Kata kunci: evaluasi; perawat ruang operasi; safety attitude culture

Abstract. In Indonesia, the incidence of medical error is quite high as evidenced by the existence of hospital incident reports, where in 2010 there were $75 \%$ of unexpected events and in 2011 as many as $60 \%$ of cases of surgical cases or patients with surgery. Medical error is one of the unwanted events, which occurred in various countries. Therefore it begins to develop a patient safety system. In order to carry out these functions, hospital should be able to carry out management based on customer oriented and patient safety by implementing a safety attitude culture. The purpose of this study was to determine the safety attitude culture evaluation of nurses in surgery rooms of PKU Muhammadiyah Gamping. This research was a research using a mixed methods research approach; namely a quantitative method with a descriptive approach and qualitative methods with a case study approach. The population in this study was nurses in surgery room with a total sampling technique of 20 people. The questionnaire in this study referred to the Surgery room Version of Safety Attitudes Questionnaire. Quantitative data analysis used descriptive analysis; while qualitative analysis was performed by data reduction, data presentation, and drawing conclusions/verification. The results shows that overall evaluation of safety culture attitude of nurses in the surgery room summed up in the high category (75,0\%). Meanwhile based on the safety attitude culture component, namely safety climate is in the high category (85,0\%), team working climate is in the high category (90,0\%), stress recognition is in the high category (65,0\%), management perceptions is in the moderate category (75,0\%), working conditions is in the high category (60,0\%), job satisfaction is in the high category $(90,0 \%)$.

Keywords: evaluation; nurse of surgery room; safety attitude culture

\section{PENDAHULUAN}

Rumah sakit (RS) merupakan organisasi yang sangat berisiko untuk terjadinya medical error khususnya di ruang operasi karena berbagai macam tindakan dilakukan di ruang operasi. Penekanan angka medical error di bidang medis dapat meningkatkan mutu pelayanan dan meminimalisasikan biaya perawatan. Hampir 100 ribu kematian di Amerika Serikat yang dapat dicegah mengakibatkan kerugian sebanyak $\$ 9$ miliar per tahun (Indiati dkk, 2012).

Data secara nasional, angka kejadian medical error di Indonesia diperkirakan cukup tinggi sejalan dengan semakin maraknya pemberitaan di media. Laporan insiden di RS, nampak lebih dari separuh termasuk dalam kategori kejadian yang tidak diharapkan (KTD), sebagian besar 75\% kejadian di tahun 2010 dan 60\% kejadian pada tahun 2011 adalah kasus bedah atau pasien dengan tindakan operasi. Insiden keselamatan pasien adalah setiap kejadian yang tidak disengaja dan kondisi yang mengakibatkan atau berpotensi mengakibatkan cedera yang dapat dicegah pada pasien yaitu kejadian tidak diharapkan (KTD), kejadian nyaris cidera (KNC), kejadian tidak cidera (KTC), dan 
kejadian potensi cidera (KPC) (Permenkes RI No 1691, 2011).

Pembedahan merupakan tindakan medis yang penting dalam pelayanan kesehatan dan salah satu tindakan yang bertujuan untuk menyelamatkan nyawa, mencegah kecacatan dan komplikasi. Namun demikian, pembedahan juga dapat menimbulkan komplikasi yang dapat membahayakan nyawa (Haynes dkk, 2009). Bidang pelayanan bedah merupakan bagian yang sering menimbulkan kejadian tidak diharapkan atau medical error, baik cidera medis maupun komplikasi akibat pembedahan. Penelitian di Utah Colorado Medical Practise Study melaporkan angka insidensi kejadian tidak diharapkan per tahun dari pasien yang mengalami pembedahan sebesar 3\% dan separuh dari kasus tersebut dapat dicegah (Sandrawati, 2013).

Medical error salah satunya kejadian yang tidak diinginkan (KTD), yang terjadi di berbagai Negara tersebut maka mulai dikembangkan sistem keselamatan pasien (patient safety). Agar dapat menjalankan fungsi tersebut, rumah sakit harus mampu menjalankan manajemen yang berprinsip pada customer oriented dan patient safety dengan menerapkan safety culture. Menurut Blegen dkk (2008) budaya keselamatan merupakan fenomena global dan mencakup normanorma, nilai-nilai, dan asumsi dasar seluruh organisasi. Di sisi lain, lebih spesifik dan mengacu pada persepsi karyawan dari aspek-aspek tertentu dari budaya organisasi. Keselamatan pasien rumah sakit adalah suatu sistem dalam membuat asuhan pasien lebih aman yang meliputi pengkajian risiko, identifikasi dan pengelolaan hal yang berhubungan dengan risiko pasien, pelaporan dan analisis insiden.

Keselamatan (safety) telah menjadi isu global termasuk juga untuk rumah sakit dan merupakan prioritas utama untuk dilaksanakan dan hal tersebut terkait dengan isu mutu dan citra rumah sakit. Budaya keselamatan (safety culture) mengacu pada cara keselamatan pasien dan dilaksanakan dalam suatu organisasi dan struktur serta proses di tempat untuk mendukung. Perawat adalah salah satu tenaga kesehatan yang berada paling depan pelayanan kesehatan mempunyai peran yang sangat penting dalam peningkatan patient safety. Perawat berada dalam posisi unik untuk meningkatkan keselamatan pasien (patient safety) karena kedekatannya yang melekat kepada pasien. Posisi ini memberikan wawasan yang diperlukan perawat untuk mengidentifikasi masalah dalam sistem kesehatan dan menjadi bagian dari solusi keselamatan pasien (patient safety) (Musliha, 2010).

Iklim keselamatan bagian dari budaya yang lebih luas dan mengacu kepada sikap tenaga kesehatan khusunya perawat tentang keselamatan pasien dalam organisasi. Mengevaluasi budaya keselamatan atau iklim sangatlah penting karena budaya organisasi dan sikap tim mempengaruhi hasil keselamatan pasien dan langkah-langkah ini dapat digunakan untuk memantau perubahan dari waktu ke waktu. Semakin berjalannya waktu dan berkembangannya kualitas pelayanan yang baik semakin meningkat pula pasien yang berobat di rumah sakit ini dengan berbagai macam penyakit yang diderita. Kompleksnya jenis penyakit, sarana medis dan petugas medis harus menerapkan standar keselamatan pasien.

\section{METODE}

Penelitian ini merupakan penelitian yang menggunakan pendekatan mixed methods research yaitu metode kuantitatif dengan pendekatan deskriptif dan metode kualitatif dengan pendekatan studi kasus (case $s t u d y$ ). Populasi dalam penelitian ini adalah perawat ruang operasi dengan teknik pengambilan sampel total sampling sampel 20 orang. Kuesioner dalam penelitian ini mengacu pada Operating Room Version of Safety Attitudes Questionnaire yang dilakukan oleh Liying Zheng (2012) yang meliputi enam indikator dalam Safety Attitudes Culture. Analisis data kuantitatif menggunakan analisis deskriptif sedangkan analisis kualitatif dilakukan dengan reduksi data, penyajian data, dan penarikan kesimpulan/verifikasi.

\section{HASIL DAN PEMBAHASAN \\ Hasil}

\section{Safety Attitude Culture}

Kategori jawaban responden untuk variabel safety attitude culture sebagian besar berada pada kategori tinggi sebanyak 15 responden $(75,0 \%)$, kategori sedang sebanyak 5 responden $(25,0 \%)$ dan tidak ada kategori rendah. Variabel safety attitude culture, dijabarkan dalam gambar berikut:

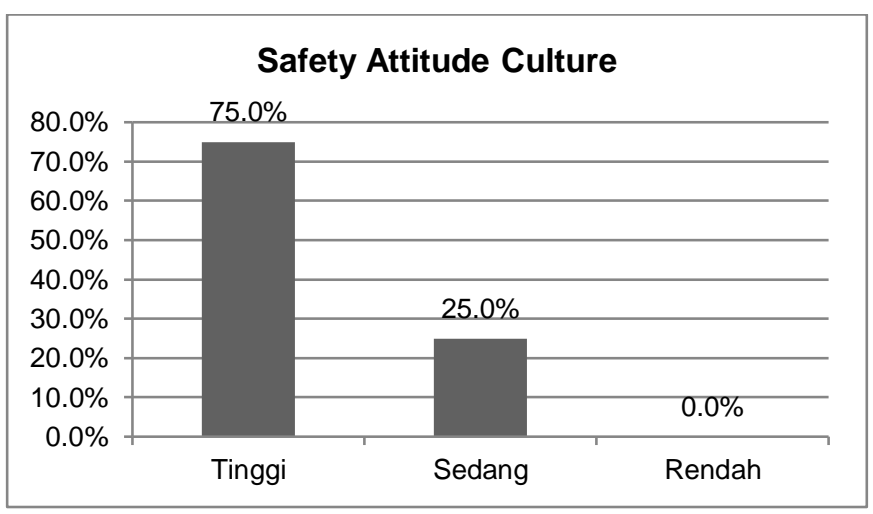

Gambar1. Kategori Jawaban Responden Terhadap Variabel Safety Attitude Culture

\section{Iklim Keselamatan}

Kategori jawaban responden untuk variabel iklim keselamatan diketahui sebagian besar berada pada kategori tinggi sebanyak 17 responden $(85,0 \%)$, kategori sedang sebanyak 3 responden $(15,0 \%)$ dan tidak ada responden dengan kategori rendah. Variabel iklim keselamatan, dapat dijabarkan dalam gambar berikut: 


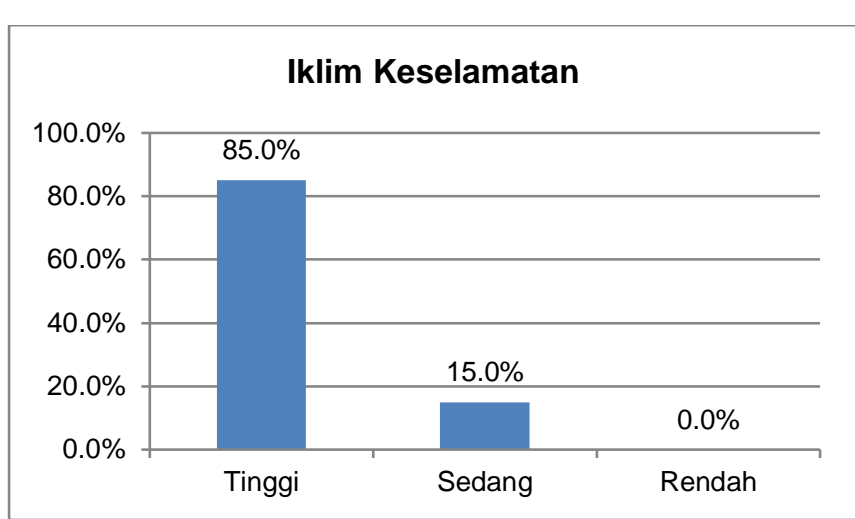

Gambar 2. Kategori Jawaban Responden Terhadap Variabel Iklim Keselamatan

\section{Iklim Kerja Tim}

Kategori jawaban responden untuk variabel iklim kerja tim sebagian besar berada pada kategori tinggi sebanyak 18 responden $(90,0 \%)$, kategori sedang sebanyak 2 responden $(10,0 \%)$ dan tidak ada kategori rendah. variabel iklim kerja tim, dapat dijabarkan dalam gambar berikut:

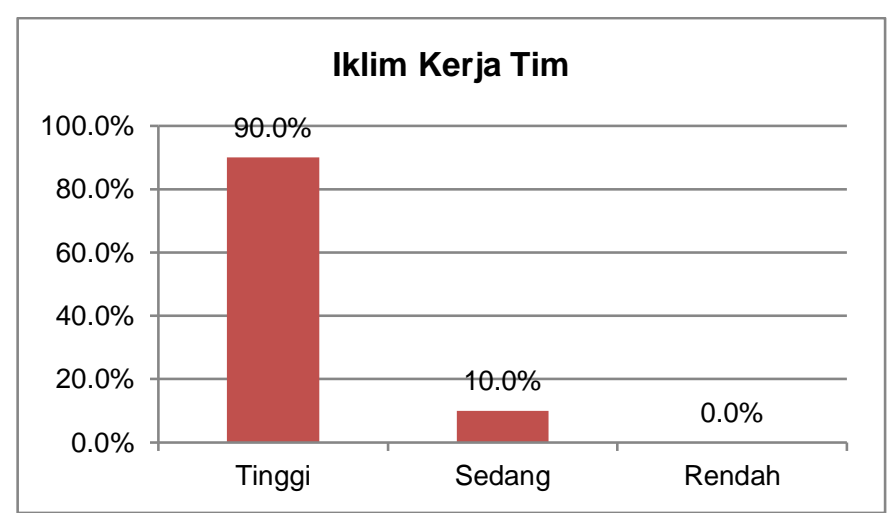

Gambar 3. Kategori Jawaban Responden Terhadap Variabel Iklim Tim Kerja

\section{Pengakuan Stres}

Kategori jawaban responden untuk variabel pengakuan stres sebagian besar berada pada kategori tinggi sebanyak 13 responden $(65,0 \%)$, kategori seang sebanyak 7 responden $(45,0 \%)$ dan tidak ada kategori rendah. Variabel pengakuan stres, dapat dijabarkan dalam gambar berikut:

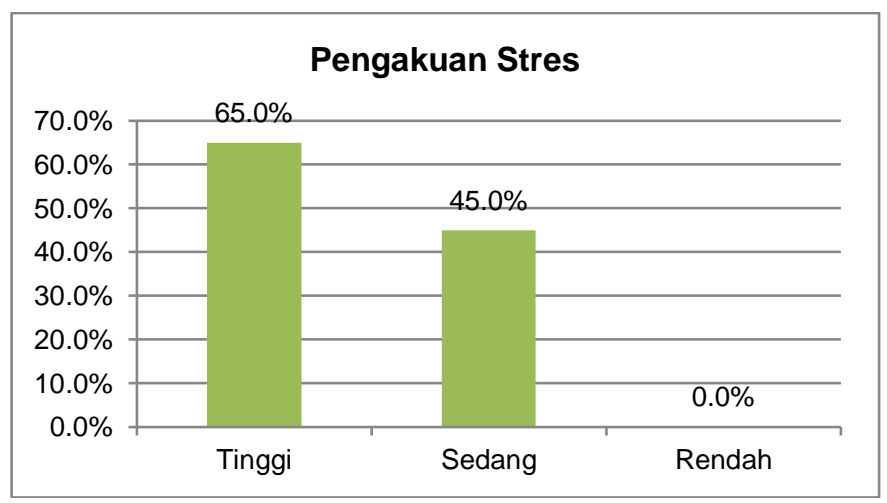

Gambar 4. Kategori Jawaban Responden Terhadap Variabel Pengakuan Stres

\section{Persepsi Manajemen}

Kategori jawaban responden untuk variabel persepsi manajemen sebagian besar berada pada kategori sedang sebanyak 15 responden $(75,0 \%)$, kategori tinggi sebanyak 4 responden $(20,0 \%)$ dan kategori rendah sebanyak 1 responden $(5,0 \%)$. Variabel persepsi manajemen, dapat dijabarkan gambar berikut:

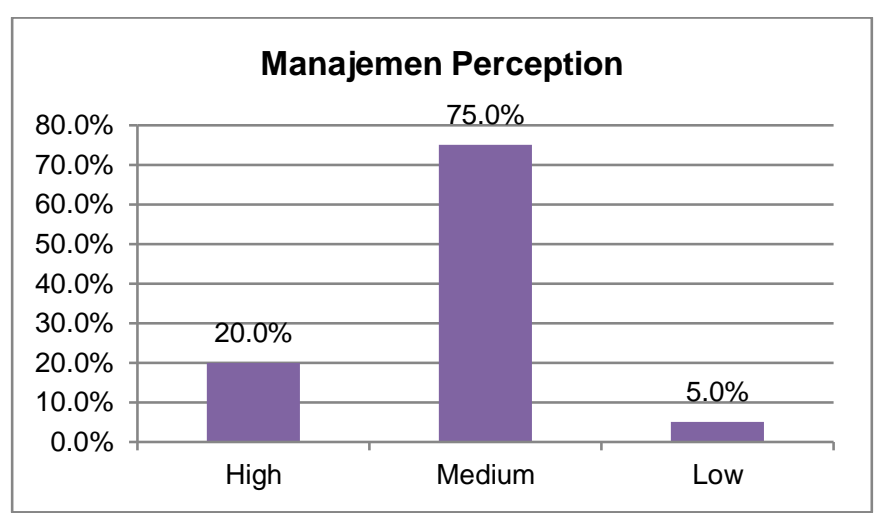

Gambar 5. Kategori Jawaban Responden Terhadap Variabel Persepsi Manajemen

\section{Kondisi Kerja}

Kategori jawaban responden untuk variabel kondisi kerja sebagian besar kondisi kerja berada pada kategori tinggi sebanyak 12 responden $(60,0 \%)$, kategori sedang sebanyak 8 responden $(40,0 \%)$ dan tidak ada kategori rendah. Variabel kondisi kerja, dapat dijabarkan dalam gambar berikut :

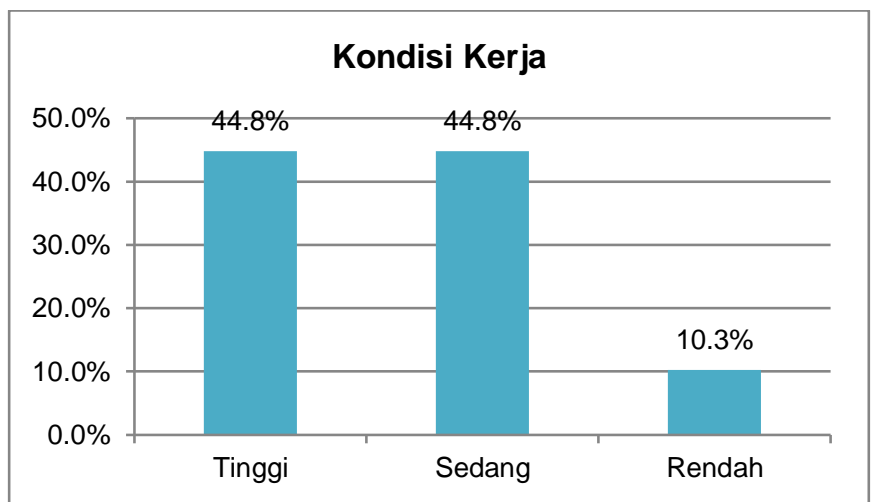

Gambar 6. Kategori Jawaban Responden Terhadap Variabel Kondisi Kerja

\section{Kepuasan Kerja}

Kategori jawaban responden untuk variabel kepuasan kerja sebagian besar berada pada kategori tinggi sebanyak 18 responden (90,0\%), kategori sedang sebanyak 2 responden $(10,0 \%)$ dan tidak ada kategori rendah. Variabel kepuasan kerja, maka dapat dijabarkan dalam gambar berikut : 


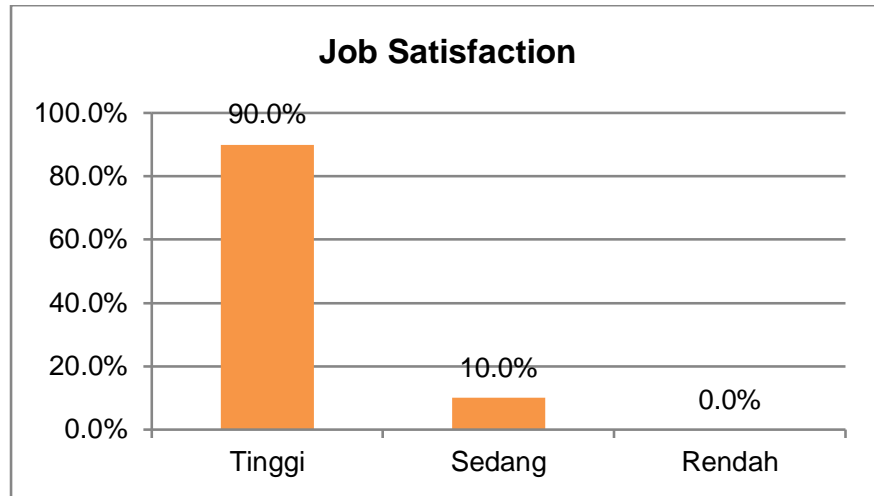

Gambar 7. Kategori Jawaban Responden Terhadap Variabel Kepuasan Kerja

\section{Pembahasan}

Safety attitude culture merupakan salah satu aspek dalam menjalankan manajemen yang berprinsip pada orientasi pelanggan dan keselamatan pasien. Safety attitude culture yang tinggi dimiliki oleh perawat akan meningkatkan kualitas perawatan pasien terutama pasien yang berada pada ruang operasi. Hal tersebut dapat mencegah terjadinya medical error perawat dalam melaksanakan asuhan keperawatan kepada pasien rumah sakit. Semakin tinggi safety attitude culture diharapkan dapat meningkatkan kinerja yang baik bagi perawat, meningkatkan keselamatan pasien sehingga hal tersebut berdampak pada isu mutu dan citra rumah sakit yang sekarang ini semakin menjadi prioritas bagi rumah sakit. Penelitian ini sejalan dengan Rivai dkk (2016) yang menunjukkan budaya keselamatan pasien mayoritas kategori baik.

Penelitian diketahui safety attitude culture yang paling tinggi adalah iklim kerja tim. Penelitian sejalan dengan Rivai dkk (2016) menunjukkan kerjasama tim mayoritas baik. Penelitian lain oleh Mulyati dkk (2016) menjelaskan sebaian besar perawat menyatakan tim kerja mendukung terhadap budaya keselamatan pasien. Perbedaan nilai dan norma serta pola berfikir perawat dalam pencapaian tujuan keperawatan sehingga dapat meminimalkan friksi yang dapat menimbulkan gangguan ada atmosfer kerja tim. Carvalho et al. (2015) juga menjelaskan tim yang terkoordinasi, dengan komunikasi yang baik dan bekerja sama, menghasilkan perawatan yang lebih manusiawi dan menghindari situasi berisiko tinggi bagi pasien.

Iklim kerja tim yang tinggi ditunjukkan dengan perawat yang merasa pendapat perawat dapat diterima dengan baik, melakukan diskusi dengan baik ketika menemukan masalah, adanya dukungan sesama perawat, mudah bertanya kepada sesama perawat. Berdasarkan hasil wawancara diketahui bahwa perawat mengakui pernah terjadi perbedaan pendapat diantara staf peratwat maupun dengan dokter. Hal-hal yang dilakukan untuk menyelesaikan masalah dengan melalakukan diskusi dan musyawarah. Hal ini dilakukan untuk mencari solusi yang terbaik dengan mengutamakan pasien. Perawat tetap berusaha untuk menyamakan persepsi dan tindakan dari terjadinya patient safety. Penelitian Toemandoek dkk (2018) menjelaskan komunikasi yang baik antar petugas medis dengan pasien akan memberikan dampak yang positif terhadap mutu pelayanan kesehatan di suatu rumah sakit serta dimungkinkan menurunkan kesalahpahaman apabila terjadi kecelakaan, kelalaian dan ataupun malpraktik. Pelayanan kesehatan yang bermutu yaitu pelayanan kesehatan yang dapat memuaskan setiap pemakai jasa pelayanan sesuai dengan kode etik dan standar pelayanan yang telah ditetapkan.

Meskipun secara keseluruhan safety attitude culture yang tinggi, namun masih ada beberapa hal yang perlu dioptimalkan seperti dimensi persepsi manajemen. Studi oleh Mandirani dkk (2019) juga menjelaskan bahwa salah satu hambatan yang ditemui dalam pelaksanaan safety attitude culture adalah dukungan dari manajemen yang belum dimaksimalkan. Patient safety tidak hanya dipengaruhi oleh bagaimana budaya individu, namun juga sistem yang berjalan dalam organisasi tersebut. Sehingga harus dilakukan pendekatan secara personal/individu maupun sistem manajemen di dalam institusi tersebut.

Persepsi manajemen juga menjadi salah satu komponen safety attitude culture yang mengacu pada persetujuan tindakan manajerial. Manajerial yang mampu memberikan persepsi yang baik akan berpengaruh terhadap safety attitude culture yang semakin tinggi. Namun dalam penelirian ini persepsi manajemen dalam kategori sedang sehingga perlu dievaluasi dengan baik. Penelitian ini sejalan dengan Mandriani dkk (2019) bahwa dukungan manajemen termasuk dalam kategori cukup. Artinya bahwa dukungan manajemen dirasa masih kurang seperti untuk kelengkapan sarana dan kurangnya pelatihan untuk petugas dalam pelaksanaan kesalamatan pasien. Dalam membangun budaya keselamatan pasien diperlukan komitmen bersama dalam melakukan asuhan kepada pasien bebas dari kejadian yang tidak diharapkan dan tertuang dalam visi dan misi organisasi, sehingga upayaupaya dalam meningkatkan atau menciptakan budaya keselamatan pasien terintegrasi di setiap aspek proses kerja (Mulyati dkk, 2016).

Berdasarkan hasil wawancara diketahui bahwa mayoritas perawat merasa peran pihak manajemen dalamhal penerapan safety attitude culture di ruang operasi sudah dijalankan baik. Peran sudah baik dan tepat karena manajemen sudah sering memberikan pelatihan sehingga informasi terkait safety attitude culture suah memadai. Penelitian oleh Mandriani dkk (2019) menjelaskan bahwa dimensi keterbukaan informasi dalam budaya keselamatan pasien termasuk kategori cukup. Keterbukaan informasi merupakan kunci untuk melaksanakan kesehatan yang baik. Kesalahan komunikasi dapat mengakibatkan resiko insiden keselamatan pasien dapat meningkat. 


\section{SIMPULAN}

Berdasarkan hasil penelitian diketahui bahwa safety attitude culture perawat yang tinggi akan meningkatkan kualitas perawatan pasien terutama pasien yang berada pada ruang operasi. Hal tersebut dapat mencegah terjadinya medical error perawat dalam melaksanakan asuhan keperawatan kepada pasien rumah sakit. Semakin tinggi safety attitude culture diharapkan dapat meningkatkan kinerja yang baik bagi perawat, meningkatkan keselamatan pasien sehingga hal tersebut berdampak pada isu mutu dan citra rumah sakit.

persepsi manajemen merupakan komponen yang paling rendah dalam safety attitude culture. Disarankan manajemen rumah sakit untuk menciptakan pengaturan yang paling efisien dan efektif untuk safety attitude culture yang sudah baik. Manajemen harus memastikan bahwa jam kerja perawat sesuai dengan peraturan, merencanakan shift mereka sedemikian rupa untuk memberi mereka waktu yang cukup untuk istirahat, dan memberikan dukungan untuk memasukkan budaya keselamatan pasien di institusi.

\section{DAFTAR PUSTAKA}

Blegen MA, Pepper GA, Rosse J. 2008. Safety Climate on Hospital Units: A New Measure.' Advances in Patient Safety. Available online at http://www.ahrq.gov/downloads/pub/ advances/vol4/blegen.pdf

Carvalho, P.A., Göttems, L.B.D., Pires, M.R.G.M, and Oliveira, M.L.C. 2015. Safety Culture in The Operating Room of a Public Hospital in The Perception of Healthcare Professionals. Rev. Latino-Am. Enfermagem, 23(6):1041-8.

Haynes AB, Weisher TG, Berry WR, Lipsits SR, Breizat A. Hadi S, Dellinger EP, Herbosa T, et al. 2009. A Surgical Safety Checklist to Reduce Morbidity and Mortality in a Global Population. N Engl J Med; 360:491-499.

Indiati, Wardhani, dan Sri Andarini. 2012. Healthcare Failure Mode and Effect Analysis: Proses Pelayanan Operasi di Rumah Sakit. Jurnal Manajemen Pelayanan Kesehatan, 15(04): 166 174

Mandriani, E., Hardisman, dan Tetti, H. 2019. Analisis Dimensi Budaya Keselamatan Pasien Oleh Petugas Kesehatan di RSUD dr Rasidin Padang Tahun 2018. Jurnal Kesehatan Andalas, 8(1), http://jurnal.fk.unand.ac.id.

Mulyati, L., Rachman, D., dan Herdiana, Y. 2016. Faktor Determinan yang Memengaruhi Budaya Keselamatan Pasien di RS Pemerintah Kabupaten Kuningan. Jurnal Keperawatan Padjadjaran, 4(2).

Musliha. 2010. Keperawatan Gawat Darurat. Yogyakarta: Nuha Medika.

Permenkes RI, 1691/Menkes/Per/VIII/ 2011 tentang Keselamatan Pasien Rumah Sakit.
Rivai, F., Sidin, A.I., dan Kartika, I. 2016. Faktor yang Berhubungan dengan Implementasi Keselamatan Pasien di RSUD Ajjappannge Soppeng Tahun 2015. Jurnal Kebijakan Kesehatan Indonesia, 05(04); 152-157.

Sandrawati, Juliana, Stefanus S., Thinni Nurul R. 2013. Rekomendasi untuk Meningkatkan Kepatuhan Penerapan Surgical Safety Checklist di Kamar Bedah. Buletin Penelitian Sistem Kesehatan, 17(1): 71-79.

Toemandoek, M.R., Kristanto, E., dan Lumunon, T. 2018. Faktor-Faktor yang Berhubungan dengan Penerapan Sasaran Keselamatan Pasien (Patient Safety) pada Perawat di Ruang Rawat Inap Obstetri dan Ginekologi Rumah Sakit Umum Pusat Prof. Dr. R.D. Kandou Manado. Journal Community Health, 2(7).

Zheng, L. 2012. Operating Room Version of Safety Attitudes Questionnaire -An Analysis Using Structural Equation Models. Thesis. Uppsala University. 